\title{
DÖNTÉSI BEFOLYÁS AZ EURÓPAI UNIÓ TANÁCSÁBAN: MIT HOZHAT A BREXIT?
}

\author{
KÓCZY Á. LÁSZLÓ
}

\begin{abstract}
A Brexit, azaz az Egyesült Királyságnak az Európai Unióból való kilépése jelentős gazdasági és politikai hatásokkal jár. Itt egyetlen konkrét aspektust, az Európai Unió Tanácsában való hatalmi viszonyok átrendeződését vizsgáljuk. A Lisszaboni Szerződésnek köszönhetően a kilépés nem igényel új tárgyalásokat, a Tanácsban folyó szavazási játékokat a rendelkezésre álló népességi adatok, illetve Eurostat-becslések alapján modellezzük. A Shapley-Shubik-index segítségével meghatározzuk az egyes tagországok hatalmi befolyását mind az Egyesült Királyság kilépése előtt és után, és markáns kapcsolatot találunk az országméret és a befolyás változása között.
\end{abstract}

\section{Bevezetés}

Nagy-Britannia és az Európai Unió kapcsolata soha sem volt egyszerü: kimaradtak jogelődje, az Európai Gazdasági Közösség (EGK) alapításából; az EGK ellensúlyozására 1960-ban létrehozott Európai Szabadkereskedelmi Társulás pedig nem lett igazán sikeres, tagjai a következő évben már jelezték csatlakozási szándékukat az EGK-hoz. Erre végül csak 1973-ban kerülhetett sor, miután Franciaország két alkalommal is élt vétójogával. A megszerzett tagságot az Egyesült Királyság nem becsülte meg, kilépése szinte az első naptól napirenden volt; 2013ban a Konzervatív Párt miniszterelnök-jelöltje, David Cameron ígéretet tett, hogy megválasztása esetén népszavazást tartanak a tagság kérdéséről. A többi, ahogy mondani szokás, már történelem: a 2016. június 23-án tartott népszavazásban a többség a kilépés mellett tette le a voksát. Maga a jogi aktus nem egyszerü lépés, évekig elhúzódhat, de előkészítése folyamatban van ${ }^{1}$.

Bár általában az Európai Unió bővítéséről beszélünk, Nagy-Britannia kilépése nem lenne precedens nélküli. Grönland 1985-ben döntött a kilépés mellett a halászati jogok körüli nézeteltérések miatt, de ez az első alkalom, hogy egy szuverén

\footnotetext{
${ }^{1}$ Megjegyzés: A cikk 2017-es elfogadása óta folynak a kilépési tárgyalások, a kilépés időpontja többször halasztást nyert, de a szándék változatlan.
} 
állam, amely nem mellesleg az EU egyik legnagyobb tagállama, lépne ki, s ennek várhatóan széleskörü hatásai lesznek a mindennapi életre az Egyesült Királyságban, de az EU többi tagországában is [5, 6, 17]. Mi a hatások közül csak egyet emelünk ki és vizsgálunk, az Európai Unió Tanácsában, korábbi nevén a Miniszterek Tanácsában folyó szavazásokhoz kapcsolódó hatalmi befolyás eloszlásának változását.

Az Európai Unió Tanácsa az EU egyik fö döntéshozó szerve. Szemben az Európai Parlamenttel, minden tagállamot egyetlen személy képvisel, de az országok közötti méretkülönbségeket kifejezendő a döntéshozás súlyozott, minősített többségi szavazással történik. Egy szavazás sikeres és eredményes, ha a javaslatot a tagországok legalább 55\%-a támogatta, s a támogató országok össznépessége legalább az Unió lakosságának 65\%-át adja. Ezek a szabályok a Lisszaboni Szerződésnek köszönhetők [11], míg korábban minden be-, vagy kilépést a szavazási súlyok újraosztásának vitája kísért, az új szabályok nem csak Horvátország belépését tették könnyebbé, de lehetőséget adnak arra, hogy elemezzük a Brexit utáni Tanács munkáját is, illetve, hogy további kilépések esélyét vizsgáljuk [18].

A dolgozat két fő részből áll: először röviden bemutatjuk a használt fogalmakat és jelöléseket, majd rátérünk a hatalmi viszonyok elemzésére.

\section{Fogalmak és jelölések}

Ha $N$ a szavazók, vagy játékosok halmazát jelöli, a szavazási helyzetek felírhatók $(N, v)$ egyszerü játékként, azaz olyan kooperatív, átruházható hasznosságú $v: 2^{N} \rightarrow\{0,1\}$ játékként, ahol a nyertes koalíciók értéke 1 , a veszteseké 0 . Vizsgálatunk középpontjában a szavazók hatalmi befolyása áll, ami a döntéshozó képességüket hívatott mérni. Elsősorban hatalmi indexekkel dolgozunk; ezek segítségével mérhetö a döntéshozók részesedése a döntéshozásból. Egy szavazó hatalmi indexe megmutatja, hogy ha valaki meghatározó volt egy döntésben, akkor mekkora a valószínüsége annak, hogy ez az adott szavazó volt. Gondoljunk arra, hogy a döntés egy egységnyi pénz elköltéséről szól és rögtön látható, hogy egy hatalmi index segít a költségvetésből való várható részesedések megállapításában is.

A hatalmi indexek közül az egyik legismertebb a $\phi$ Shapley-Shubik-index [22], ami lényegében a Shubik-érték [21, 19] alkalmazása egyszerű játékokra. Utóbbi nem más, mint a szavazók átlagos határhozzájárulása az aktuális $S$ koalíció $v(S)$ értékéhez véletlen érkezési sorrend esetén. Egyszerü játékok esetén a határhozzájárulás csak akkor nem 0, ha a szavazó éppen nyertessé tette a koalíciót; egy tetszőleges $(N, v)$ egyszerü játék esetén az $i$ játékos, vagy szavazó Shapley-Shubikindexe

$$
\phi_{i}(v)=\sum_{S \subseteq N \backslash\{i\}} \frac{s !(n-s-1) !}{n !}(v(S \cup\{i\})-v(S)),
$$

ahol $s=|S|$. Hasonlóan elismert a Banzhaf-index, s bár a kettő között jelentős szemléletbeli különbség van, értékükben alig térnek el. Érdekes megemlíteni, hogy 
a Shubik-érték számtalan elosztási probléma megoldásában segít legyen szó költségmegosztásról egy öntözési játékban [15], vagy kockázatelosztásról [2, 1], illetve a szavazási modell hiányzással való kiegészítése hasonló, általánosabb játékokhoz vezet [14].

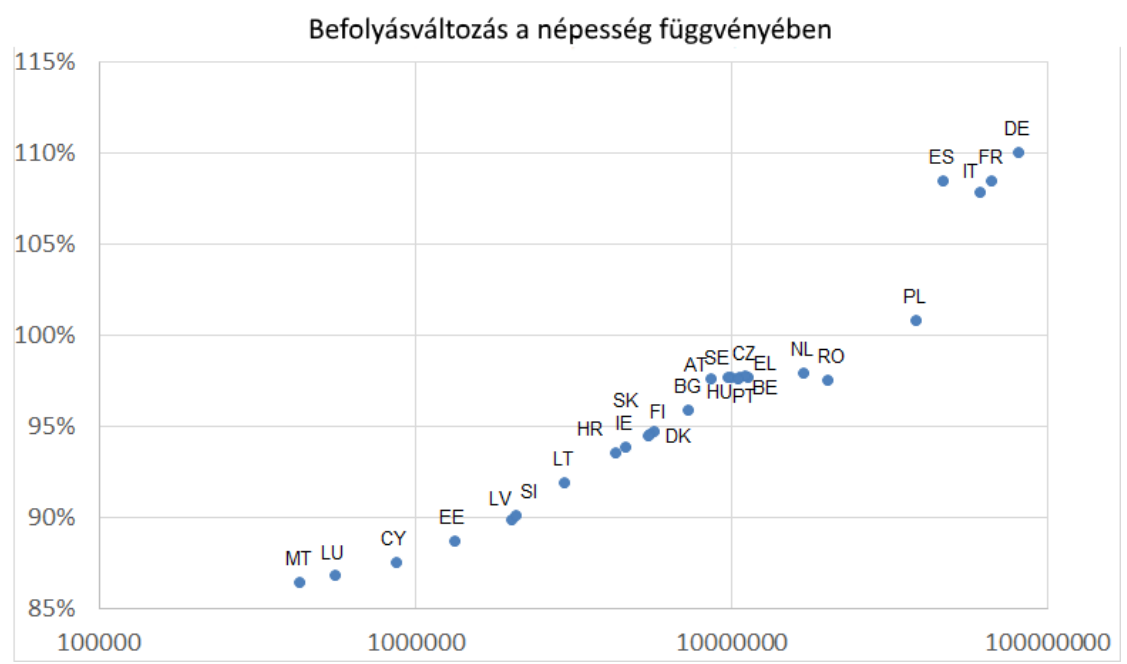

1. ábra. Módosított hatalmi indexek a jelenlegiek százalékában és a népességek függvényében.

\section{Adatok és eredmények}

Az Európai Unió Tanácsában folyó szavazás a népességi adatokon is múlik; a szükséges népességszámokhoz és ezek 2080-ig szóló előrejelzéseihez az Eurostat [8] adatait használtuk. A számításokat az IOP - Indices of Power 2.05 [4] program segítségével végeztük.

A kapott hatalmi változások többnyire elöre láthatók. Az új tagok tulajdonság [3, 10] szerint egy tag, például az Egyesült Királyság távozása - többnyire - növeli a több hatalmi befolyását, és valóban a legtöbb tag, különösen a nagyobb népességü tagok Shapley-Shubik-indexe nő. Ezzel szemben a Lettországnál is kisebb országok esetében az új tag paradoxon [23, 20] figyelhető meg, azaz befolyásuk a kilépés ellenére csökken.

No de vajon a nagy országok jól járnak-e? Bár az évek alatt az Egyesült Királyság jelentős kedvezményeket harcolt ki magának, továbbra is jelentős befizető, a Unió költségvetésének 8,8\%-át az Egyesült Királyság adja [7]. A Brexit után 91,2\%-ára csökken a költségvetés, így az ebből számolt szeletek értéke is. Ha „forintosítani" szeretnénk a Brexit hatását, akkor a kapott indexeket is korrigálni kell. 
Az 1. ábrán jól látható, hogy a 6 milliónál kisebb lakosságú országok jelentős, akár 15\%-os veszteséget szenvednek, csak a 20 millió felettiek, különösen a négy legnagyobb: Francia-, Német-, Olasz- és Spanyolország nyer. További eredményeket [13] és [18] közöl.

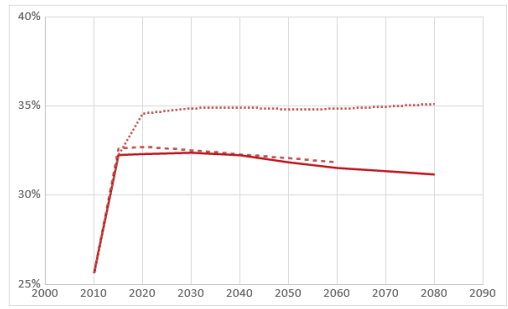

(a) Az Unió magja

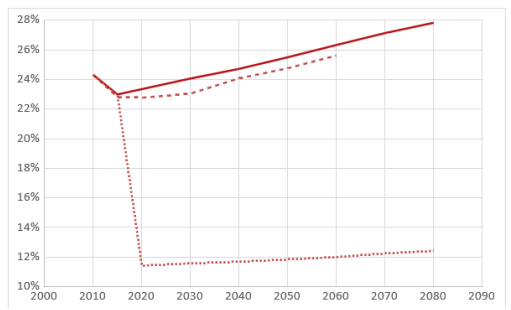

(c) Észak-Európa, Baltikum, Ausztria

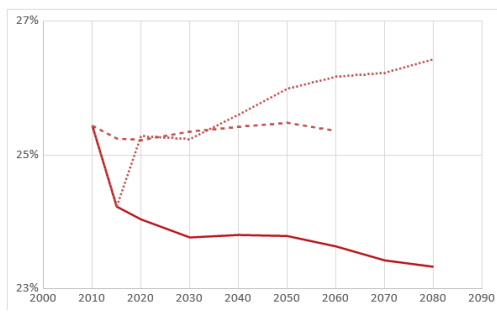

(b) Dél-Európa

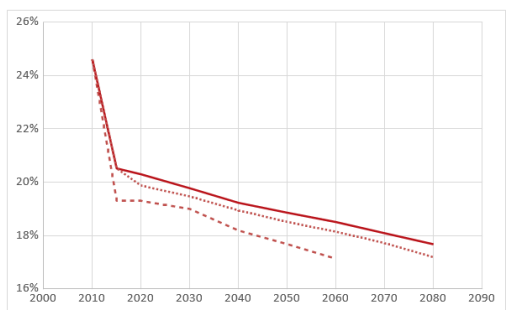

(d) Közép-Kelet Európa

2. ábra. Hatalmi index előrejelzések négy országcsoportra. (A 2010-es [12], aktualizált és Brexit utáni értékek szaggatott, folytonos és pontozott vonallal.)

\section{Konklúzió}

Elemzők [16] szerint az Egyesült Királyság célja a kilépés helyett a kedvezőbb tagsági feltételek kiharcolása volt. London a pénzügyi, üzleti világ egyik központja, Európa számára nélkülözhetetlen, gondolhatnánk. A Brexit, mint fenyegetés meg kellett volna tegye a hatást, s várható volt, hogy miután az Egyesült Királyság (ismét) térdre kényszerítette a Kontinenst, a választók szívesen támogatnak egy ilyen Uniót. Nem ez történt. Az Egyesült Királyság a kezdetektől fogva problémás tag volt, nincs még egy ország, ami akár közel annyiszor állt volna a kisebbségi vélemény mellé [9]. Bár elemzésünk a problémakörnek csak egy kicsi részét vizsgálja, úgy tünik, hogy az Unió véleményformáló országai kötségvetési szempontból kifejezetten jól járnak a Brexittel (2. ábra). Az eredményt már ismerjük. A tárgyalások minimális, inkább szimbolikus engedményeket hoztak csak, a terv fordítva sült el. Kommunikálható eredmények hiányában a hivatalos kampány is csalódott, erőtlen volt, s végül a szavazók többségükben a kilépés mellett döntöttek. 


\section{Köszönetnyilvánítás}

A szerző köszöni az MTA (LP-004/2010) és az NKFIH (K-109354 és K-128573) támogatását.

\section{Hivatkozások}

[1] Balog, D., BÁTYI, T. L., CsóKA, P., ÉS PintéR, M.: Tőkeallokációs módszerek és tulajdonságaik a gyakorlatban, Közgazdasági Szemle, Vol. 58 No. 7-8, pp. 619-632 (2011).

[2] Balog, D., CsóKa, P., ÉS PintéR, M.: Tőkeallokáció nem likvid portfóliók esetén, Hitelintézeti Szemle, Vol. (6), (2010), 604-616.

[3] Brams, S. J. and Affuso, P. J.: Power and size: A new paradox, Theory and Decision, Vol. 7 No. 1-2, pp. 29-56 (1976). DOI: 10.1007/BF00141101

[4] Bräuninger, T. And König, T.: Indices of Power IOP 2.0 (2005).

[5] Buckle, R., Hewish, T., Hulsman, J. C., Mansfield, I., and Oulds, R.: Directions for Britain outside the EU, Institute or Economic Affairs, London (2015).

[6] Dagnis Jensen, M. And Snaith, H.: When politics prevails: the political economy of a Brexit, Journal of European Public Policy, Vol. 1763, pp. 1-9 (2016). DOI: 10.1080/13501763.2016.1174531

[7] European Parliament: EU budget explained: expenditure and contribution by member state. United Kingdom (2015), http://www.europarl.europa.eu/news/en/newsroom/20141202IFG82334/EU-budget-explained-expenditure-and-contribution-bymember-state.

[8] Eurostat: EUROPOP2013 - Convergence scenario, national level, Population predictions - [tps00002] (2014).

[9] Hix, S., Hagemann, S., and Frantescu, D.: Would Brexit Matter? The UK's Voting Record in the Council and the European Parliament, Techn. Ber. April, VoteWatch Europe, Brussels (2016), http://www.votewatch.eu/blog/special-report-would-brexit-matterthe-uks-voting-record-in-the-council-and-the-european-parliament/.

[10] Kóczy, L. Á.: Measuring Voting Power: The paradox of new members vs. the null player axiom, in: Rudas, I. J., Fodor, J., AND KACPRZYK, J. (Hg.), Towards Intelligent Engineering and Information Technology, pp. 67-78, Springer, Berlin (2009). DOI: 10.1007/9783-642-03737-5_5

[11] Kóczy, L. Á.: Lisszaboni kilátások, Közgazdasági Szemle, Vol. 58 No. 10, pp. 1045-1058 (2011).

[12] Kóczy, L. Á.: Beyond Lisbon: Demographic trends and voting power in the European Union Council of Ministers, Mathematical Social Sciences, Vol. 63 No. 2, pp. 152-158 (2012). DOI: 10.1016/j.mathsocsci.2011.08.005

[13] Kóczy, L. Á.: How Brexit affects European Union power distribution, HAS-CERS Discussion Paper, MT-DP - 2016/11, (2016). DOI: 10.2139/ssrn.2781666

[14] Kóczy, L. Á. És PINTÉR, M.: Az ellenzék ereje - általánosított súlyozott szavazási játékok, Közgazdasági Szemle, Vol. 58 No. 6, pp. 543-551 (2011).

[15] KovÁcs, G. ÉS RAdvÁNyi, A.: Költségelosztási modellek, Alkalmazott Matematikai Lapok, Vol. 28, pp. 59-76 (2011). 
[16] Kroll, D. A. And Leuffen, D.: Ties that bind, can also strangle: the Brexit threat and the hardships of reforming the EU, Journal of European Public Policy, Vol. 23 No. 9, pp. 1311-1320 (2016). DOI: 10.1080/13501763.2016.1174532

[17] Oliver, T.: European and international views of Brexit, Journal of European Public Policy, Vol. 23 No. 9, pp. 1321-1328 (2016). DOI: 10.1080/13501763.2016.1174534

[18] Petróczy, D. G., Rogers, M. És Kóczy, L. Á.: Tagkilépések és a magyar befolyás változása az Európai Unió Tanácsában, Alkalmazott Matematikai Lapok, Vol. 36, pp. 65-81 (2019).

[19] Pintér, M.: A Shapley-érték axiomatizálásai, Alkalmazott Matematikai Lapok, Vol. 26, (2009), pp. 289-315.

[20] Rusinowska, A. And van Deemen, A.: The Redistribution Paradox and the Paradox of New Members in the German Parliament, in: Petrosyan, L. A. and Mazalov, V. V. (Hg.), Game Theory and Applications, pp. 153-174, Nova, New York (2005).

[21] Shapley, L. S.: A Value for n-Person Games, in: Kuhn, H. W. And Tucker, A. (Hg.), Contributions to the Theory of Games, Bd. II, pp. 307-317, Princeton University Press (1953). DOI: 10.1515/9781400881970-018

[22] Shapley, L. S. And Shubik, M.: A method for evaluating the distribution of power in a committee system, American Political Science Review, Vol. 48 No. 3, pp. 787-792 (1954). DOI: $10.2307 / 1951053$

[23] van Deemen, A. And Rusinowska, A.: Paradoxes of voting power in Dutch politics, Public Choice, Vol. 115 No. 1/2, pp. 109-137 (2003). DOI: 10.1023/A:1022827428428

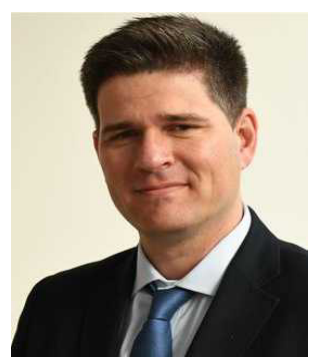

Kóczy Á. László 1976-ban született Budapesten. Matematikus BA (University of Cambridge, 1997), közgazdász MSc (KU Leuven, 1999), majd PhD (KU Leuven, 2003) fokozatot szerzett, 2019-ben habilitált (BME). 2003-2009 között adjunktus a Maastrichti Egyetemen, 2007-2019 között főiskolai tanár a Budapesti Müszaki Főiskolán, majd docens az Óbudai Egyetemen. 2010-ben az MTA Lendület programjának támogatásával megalakította az MTA Közgazdaságtudományi Intézetben a Játékelméleti Kutatócsoportot, azóta az intézet tudományos főmunkatársa, 2019 óta a BME Gazdaság- és Társadalomtudományi Karának docense. Tagja az MTA Közgazdaság-tudományi Bizottságának és az MTMT Tudománymetriai Szakbizottságának. A Magyar Közgazdaságtudományi Egyesület alapító tagja, korábbi elnöke, a Game Theory Society, a Society for Social Choice and Welfare, az Econometric Society, a European Economic Association tagja. Kutatási területe a játékelmélet. Egy könyv, 27 angol, 12 magyar nyelvü cikk szerzője, független hivatkozásainak száma 390, h-indexe 9.

\section{KÓCZY Á. LÁSZLÓ}

Közgazdaság- és Regionális Tudományi Kutatóközpont

Közgazdaságtudományi Intézet

1097 Budapest, Tóth Kálmán u. 4.

koczy@krtk.mta.hu 


\title{
POWER DISTRIBUTION IN THE COUNCIL OF THE EUROPEAN UNION: WHAT A DIFFERENCE WILL BREXIT MAKE?
}

\begin{abstract}
LÁSZLÓ Á. KóCZY
The possible exit of the United Kingdom from the European Union will have profound economic and political effects. Here we look at a particular aspect, the power distribution in the Council of the European Union. Since the Lisbon treaty the exit does not require new negotiations as the success of a voting initiative depends only on the number and total population of the supporting member states. Using the Shapley-Shubik power index we calculate the member states' powers with and without the United Kingdom and update earlier power forecasts using the Eurostat's latest population projections. There is a remarkably sharp relation between population size and the change in power: Brexit increases the largest members', while decreases the smallest ones' powers.
\end{abstract}

Keywords: European Union, Council of the European Union, qualified majority voting, power index, a priori voting power, demographics.

Mathematics Subject Classification (2000): 91A12, 91A80, 91F10. 